\title{
Dynamics of insecticide resistance in malaria vectors in Benin: first evidence of the presence of L1014S kdr mutation in Anopheles gambiae from West Africa
}

Innocent Djègbè ${ }^{1,2^{*}}$, Olayidé Boussari ${ }^{1}$, Aboubakar Sidick$^{1}$, Thibaud Martin ${ }^{3}$, Hilary Ranson ${ }^{4}$, Fabrice Chandre ${ }^{5}$, Martin Akogbéto ${ }^{1}$ and Vincent Corbel ${ }^{1,2}$

\begin{abstract}
Background: Insecticide resistance monitoring is essential to help national programmers to implement more effective and sustainable malaria control strategies in endemic countries. This study reported the spatial and seasonal variations of insecticide resistance in malaria vectors in Benin, West Africa.
\end{abstract}

Methods: Anopheles gambiae s.l populations were collected from October 2008 to June 2010 in four sites selected on the basis of different use of insecticides and environment. WHO susceptibility tests were carried out to detect resistance to DDT, fenitrothion, bendiocarb, permethrin and deltamethrin. The synergist piperonyl butoxide was used to assess the role of non-target site mechanisms in pyrethroid resistance. Anopheles gambiae mosquitoes were identified to species and to molecular $\mathrm{M}$ and $\mathrm{S}$ forms using PCR techniques. Molecular and biochemical assays were carried out to determine $k d r$ and $A c e .1^{R}$ allelic frequencies and activity of the detoxification enzymes.

Results: Throughout the surveys very high levels of mortality to bendiocarb and fenitrothion were observed in An. gambiae s.l. populations. However, high frequencies of resistance to DDT and pyrethroids were seen in both M and $\mathrm{S}$ form of An. gambiae s.s. and Anopheles arabiensis. PBO increased the toxicity of permethrin and restored almost full susceptibility to deltamethrin. Anopheles gambiae s.l. mosquitoes from Cotonou and Malanville showed higher oxidase activity compared to the Kisumu susceptible strain in 2009, whereas the esterase activity was higher in the mosquitoes from Bohicon in both 2008 and 2009. A high frequency of $1014 \mathrm{~F} \mathrm{kdr} \mathrm{allele} \mathrm{was} \mathrm{initially} \mathrm{showed}$ in An. gambiae from Cotonou and Tori-Bossito whereas it increased in mosquitoes from Bohicon and Malanville during the second year. For the first time the $L 10145 \mathrm{kdr}$ mutation was found in An. arabiensis in Benin. The ace. $1^{R}$ mutation was almost absent in An. gambiae s.l.

Conclusion: Pyrethroid and DDT resistance is widespread in malaria vector in Benin and both metabolic and target site resistance are implicated. Resistance was not correlated with a change of malaria species and/or molecular forms. The $1014 \mathrm{~S} \mathrm{kdr}$ allele was first identified in wild population of An. arabiensis hence confirming the expansion of pyrethroid resistance alleles in Africa.

\footnotetext{
*Correspondence: djegbe1@yahoo.fr

${ }^{1}$ Centre de Recherche Entomologique de Cotonou (CREC), 06 BP 2604

Cotonou, Bénin

Full list of author information is available at the end of the article
} 


\section{Background}

Despite intense national and international efforts, malaria remains one of the major tropical challenges in the world today [1]. In Benin, the primary tools for malaria vector control are long-lasting insecticidal nets (LLIN) and indoor residual spraying (IRS). However, insecticide resistance development in vector populations could impede the success of malaria control programmes in endemic areas. In West Africa, the resistance of Anopheles gambiae s.l. to the four major classes of insecticides available for public health has been reported [2-4].

Pyrethroids are the only option for net treatment due to their relative safety for humans at low dosage, excitorepellent properties, rapid rate of knock-down and killing effects [5].

Resistance to this insecticide class is now widespread in the main malaria vectors An. gambiae s.l, Anopheles arabiensis and Anopheles funestus [6-9]. Both enhanced detoxification $[10,11]$ and mutations in the gene encoding the voltage-gated sodium channel [12] have been shown to be important resistance mechanisms. The Leucine to Phenylalanine substitution at position 1014 (L1014F) was found predominant in West and central Africa $[7,13]$ whereas the Leucine to Serine substitution (L1014S), originated from Kenya [14], has now spread in the central region including Cameroon $[15,16]$, Equatorial Guinea [17], Gabon [18], Angola [17], Uganda [19] and Ethiopia [8].

The impact of this resistance on pyrethroid-based control is largely unquantified. Until recently, pyrethroid resistance based on $k d r$ mutation or metabolic mechanisms in An. gambiae in Côte d'Ivoire [20,21] and Kenya [22,23], did not adversely affect the efficacy of pyrethroid-treated nets. However, a longitudinal survey recently conducted in southern Benin showed neither reduction of asymptomatic infection nor malaria attack by the use of LLINs in an area of pyrethroid resistance [24].

In Benin recent (2006-2007) entomological surveys reported cross-resistance to DDT and pyrethroids in An. gambiae s.l. with strong geographic variations in a south-north transect $[13,25]$. Molecular studies showed the presence of the $k d r L 1014 F$ mutation and an overexpression of two P450 genes (CYP6M2 \& CYP6P3) potentially involved in pyrethroid resistance [26]. The presence of a single point mutation (glycine to serine at position 119) in the oxyanion hole of the acetylcholinesterase enzyme $[3,27,28]$ conferring resistance to carbamates and to a lesser extend to organophosphates was also detected in Burkina-Faso, Côte d'Ivoire and Benin [13,29,30].

The intense use of DDT in agricultural settings and during the WHO malaria eradication programme in the 1950 s and 1960s were suspected to be the main factors selecting for pyrethroids and DDT resistance in An. gambiae populations [31]. Various insecticidal products (organophosphates, pyrethroids, etc.) are also used for crop protection but the amount applied is far higher than that consumed in public health against malaria vectors [2]. Benin is still an important producer of cotton in West Africa and $90 \%$ of pesticide products are directed against cotton pests [32,33]. Small-scale vegetable farming is an important source of livelihood in urban and peri-urban environments [34] and provides income and food for tens of thousands of families [35]. Akogbéto et al [31,36] reported that mosquito species, An. gambiae in particular, lay their eggs in breeding sites located around agricultural settings. These eggs undergo a selection pressure from agricultural pesticides, which leads to the emergence of resistant populations of An. gambiae, thereby impeding malaria vector control operations.

The Beninese National Malaria Control Programme received financial and technical support from World Bank, Global fund and WHO to implement large-scale and free distribution of LLIN since 2007 [37]. Several authors have studied the effect of insecticide treated nets (ITNs) with pyrethroids on An. gambiae populations and the possible selection of $k d r$ alleles either in laboratory experiments [38] or experimental huts trials [39] or in the field [40,41]. Increasing resistance of malaria vectors may have important implications for vector control programmes, especially considering the scaling up of LLINs and IRS in Africa. Hence, knowledge on spatio-temporal changes in insecticide resistance level is a basic requirement to guide the use of insecticides in malaria control programmes.

In this study, the dynamic of insecticide resistance was evaluated in An. gambiae populations collected in four sentinel sites selected on the basis of different agricultural practices, use of insecticides and environment (urban/rural areas). From 2008 to 2010, temporal changes in insecticide resistance level, sibling species among An. gambiae s.l, enzymatic activity and frequency of resistant alleles were measured twice per year through a combination of insecticide bioassay, biochemical and molecular techniques.

\section{Methods}

\section{Study area}

Four representative sites in Benin (Figure 1) were selected for the biannual resistance monitoring on the basis of expected insecticide selection pressures. These sites are Asecna, Tori-Bossito, Bohicon and Malanville. Asecna $\left(6^{\circ}\right.$ $21 \mathrm{~N}-2^{\circ} 23 \mathrm{E}$ ) is a 14 ha vegetable growing area located in Cotonou and where locals apply uncontrolled amount of insecticides for crop protection (cabbages, lettuces and tomatoes) [31]. Tori-Bossito $\left(2^{\circ} 89 \mathrm{E}-6^{\circ} 30 \mathrm{~N}\right)$ is located in the South-West of the country where farmers cultivate maize and cassava and where people used ITN and sprays for protection against malaria vectors. Bohicon $\left(2^{\circ} 49 \mathrm{E}-7^{\circ}\right.$ $11 \mathrm{~N}$ ) is located in the middle part of the country, where the farmers used significant amounts of pyrethroids and 


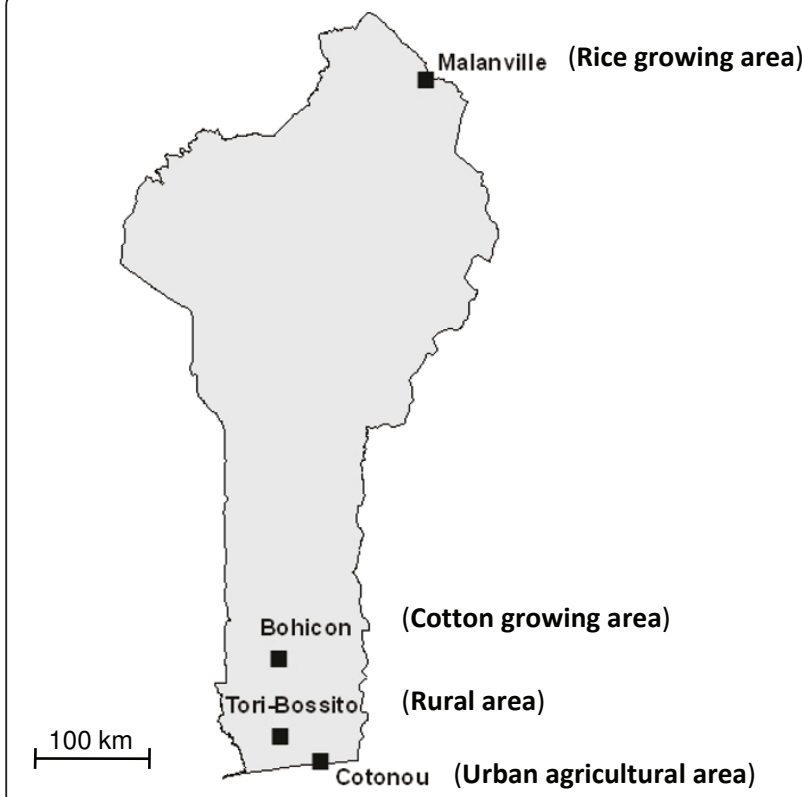

Figure 1 Map of Benin showing the mosquito collection sites.

organophosphates for cotton protection. Malanville $\left(11^{\circ}\right.$ $52 \mathrm{~N}-3^{\circ} 23 \mathrm{E}$ ) is a 100 ha rice growing area located in the far north of Benin, near the Niger River, where the insecticide use is minimal for rice protection.

\section{Mosquito collection}

From October 2008 to June 2010, larvae of An. gambiae mosquito were collected twice per year, i.e. at the beginning and the end of rainy season from a wide range of breeding sites (puddles, shallow wells, gutters and rice fields). In each locality, larval collections were carried out in, at least, 15 breeding sites in which an average of 100 larvae (all instars) per habitat were collected. All larvae were brought back to laboratory of Centre de Recherche Entomologique de Cotonou (CREC) for rearing. Emerging adult female mosquitoes $\left(\mathrm{F}_{0}\right)$ were used for insecticide susceptibility tests. A susceptible strain of An. gambiae (Kisumu) was used as reference strain for bioassays and biochemical studies.

\section{Insecticide susceptibility test}

WHO insecticide susceptibility test-kits and standard procedures [42] were used to monitor the susceptibility of wild An. gambiae populations to the four chemical groups of insecticides commonly used in public health and agriculture. Anopheles gambiae s.l. mosquitoes were first morphologically identified and then submitted to bioassays. Batches of 25 non-blood fed, 3-5 days old adult females were exposed to filter papers impregnated with $4 \%$ DDT (organochlorine), $1 \%$ fenitrothion (organophosphate), $0.1 \%$ bendiocarb (carbamate), $0.75 \%$ permethrin and $0.05 \%$ deltamethrin (pyrethroids). Insecticide papers were obtained from the WHO reference centre at the Vector Control Research Unit, University Sains Malaysia [43]. For each test, 100 mosquitoes were exposed to treated and untreated (control) papers for 1 hour. The piperonyl butoxide (PBO), an inhibitor of oxidases and esterases, was used as a synergist of pyrethroids whenever possible. In this case, mosquitoes were first exposed to PBO (4\%) during 1 hour and then to permethrin or deltamethrin as described above. The mortality was recorded after 24 hour. WHO criteria were followed to classify populations as 'resistant' if less than $80 \%$ mortality was observed, as "suspected resistant" if mortality rates were between 80 and $97 \%$ and susceptible for mortality $>97 \%$ [43].

\section{Biochemical analysis}

Biochemical assay were used to quantify levels of oxidase, non-specific esterase and GST activities in individual 2-5 days old adults of An. gambiae that have not been previously exposed to insecticides (i.e. control batches). A total of 47 specimens were tested per microtitre plate according to the method described by Hemingway [44]. Each plate contained 10 unfed adult mosquitoes from the susceptible Kisumu strain to allow for comparison with field mosquito populations.

\section{Molecular identification}

For each sentinel site, 30-50 mosquitoes taken from the control tubes were identified to species using PCR [45] and as $\mathrm{M}$ and $\mathrm{S}$ molecular forms by PCR-RFLP technique [46].

\section{PCR detection of the Kdr Leu-Phe, Leu-Ser and Ace.1 mutations}

The presence of $1014 \mathrm{~F}$ and $1014 \mathrm{~S} k d r$ alleles was tested on mosquitoes from bioassay control using HOLA (Hot Oligonucleotide Ligation Assay) technique according to protocol of Lynd et al [47]. All samples positive for the $1014 \mathrm{~S}$ allele were sent for sequencing to confirm the results. The PCR-FRLP diagnostic test was used to detect the presence of G119S mutation (Ace.1 gene) as described by Weill et al [48].

\section{Data analysis}

Data of mortality rates obtained with or without synergist were compared using a Chi-square test with the MINITAB statistical software. Biochemical assay data (enzymatic activity per mg protein) were compared between the reference strain (Kisumu) and the fieldcaught populations by a Kruskal-Wallis non-parametric test. The frequency of resistant alleles $\left(k d r\right.$ and ace. $\left.1^{R}\right)$ was compared by chi-square test implemented using GENEPOP software between species (An. gambiae M 
and $\mathrm{S}$ forms and An. arabiensis) and round collections [49].

\section{Results}

\section{Resistance status}

Figure 2 shows the insecticide resistance status of four An. gambiae s.l populations collected in Benin during 4 collection rounds (2008 to 2010). Throughout the surveys, the susceptible strain Kisumu of An. gambiae displayed mortality rates above $98 \%$ for the five insecticides tested. In control groups (untreated papers) mortality rates of wild $A n$. gambiae populations were always below $10 \% 24$ hours post-exposure.

Anopheles gambiae s.l populations collected in the four sites remained almost fully susceptible to bendiocarb and fenitrothion (Figure 2). Conversely, high frequencies of DDT and permethrin resistance were initially found at Cotonou and Tori-Bossito. A significant decrease in permethrin mortality rates was recorded between 2009 and 2010 in Malanville and Bohicon ( $\mathrm{p}<0.0001)$ but DDT resistance was already high in the latter site. Bioassays showed a global increase of deltamethrin resistance throughout the two years surveys in Tori-Bossito, Bohicon and Malanville $(\mathrm{p}<0.0001)$.

\section{Synergist and biochemical analysis}

Figure 3 shows the insecticidal activities of permethrin and deltamethrin against An. gambiae s.l. mosquitoes (June 2009 and June 2010) with and without the synergist PBO. Pre-exposure of mosquitoes to PBO significantly increased the mortality rates of permethrin and to a lesser extend deltamethrin at Cotonou, Bohicon and Malanville $(\mathrm{p}<0.05)$ in 2009 whereas in 2010 , PBO strongly enhanced the mortality rates of deltamethrin especially in Tori-Bossito and Malanville ( $\mathrm{p}<0.0001)$.

Data from biochemical analyses carried out in 2008 and 2009 (once per year: October) are shown in Figure 4. Anopheles gambiae s.l. mosquitoes collected in Cotonou and Malanville in 2009 showed significantly higher oxidase activity $(\mathrm{P}<0.05)$ compared to those of the susceptible reference strain Kisumu. Higher activity of esterase (using both $\alpha$-naphtyl and $\beta$-naphtyl acetate as
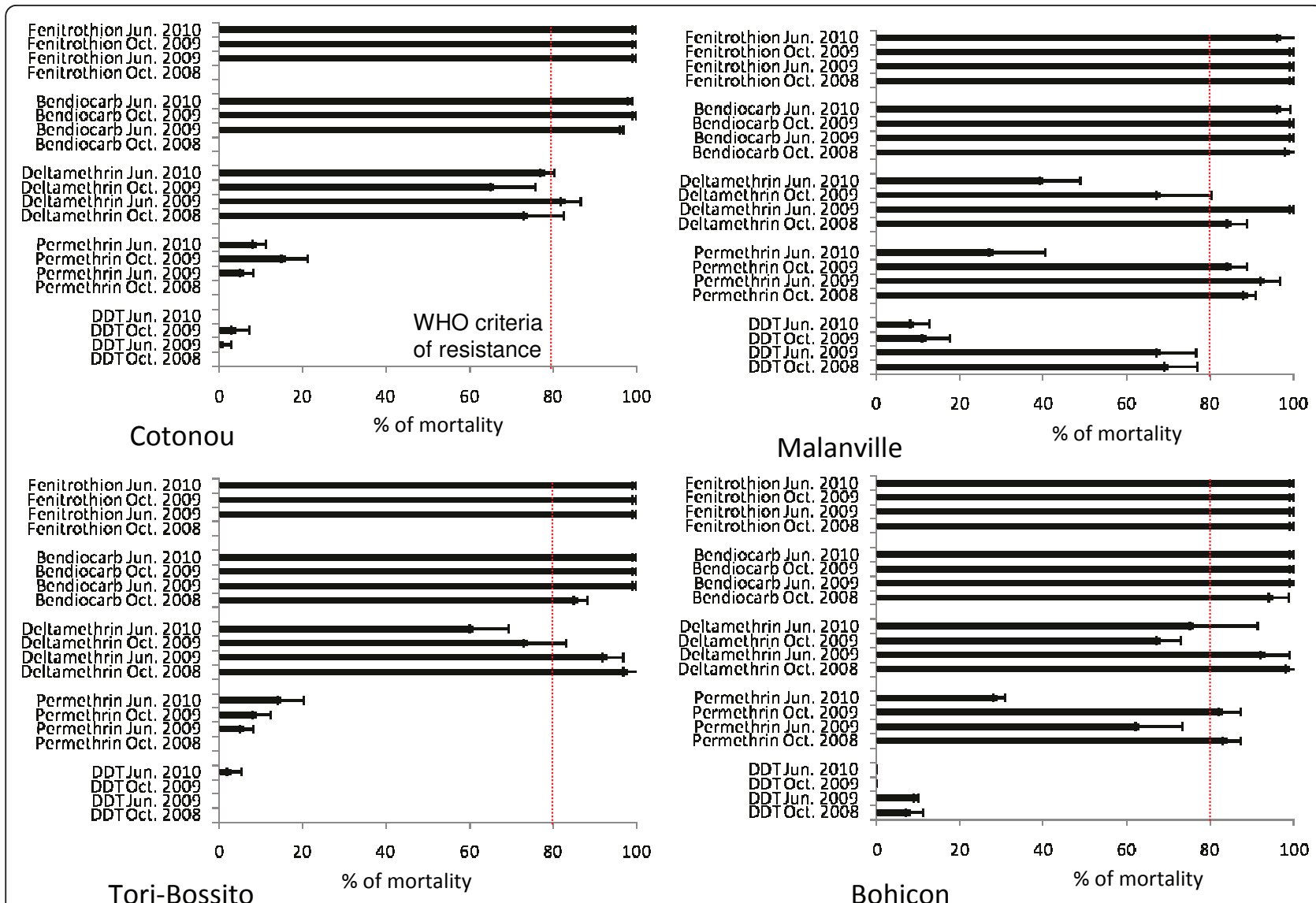

Figure 2 Insecticide susceptibility status of Anopheles gambiae s.l. in the four sentinel sites in Benin. Error bars are standard deviations. Nota: In October 2008 because of lower number of mosquitoes collected susceptibility tests were not performed with all five insecticides in Cotonou (only deltamethrin was tested) and Tori-Bossito (only deltamethrin and bendiocarb were tested). 


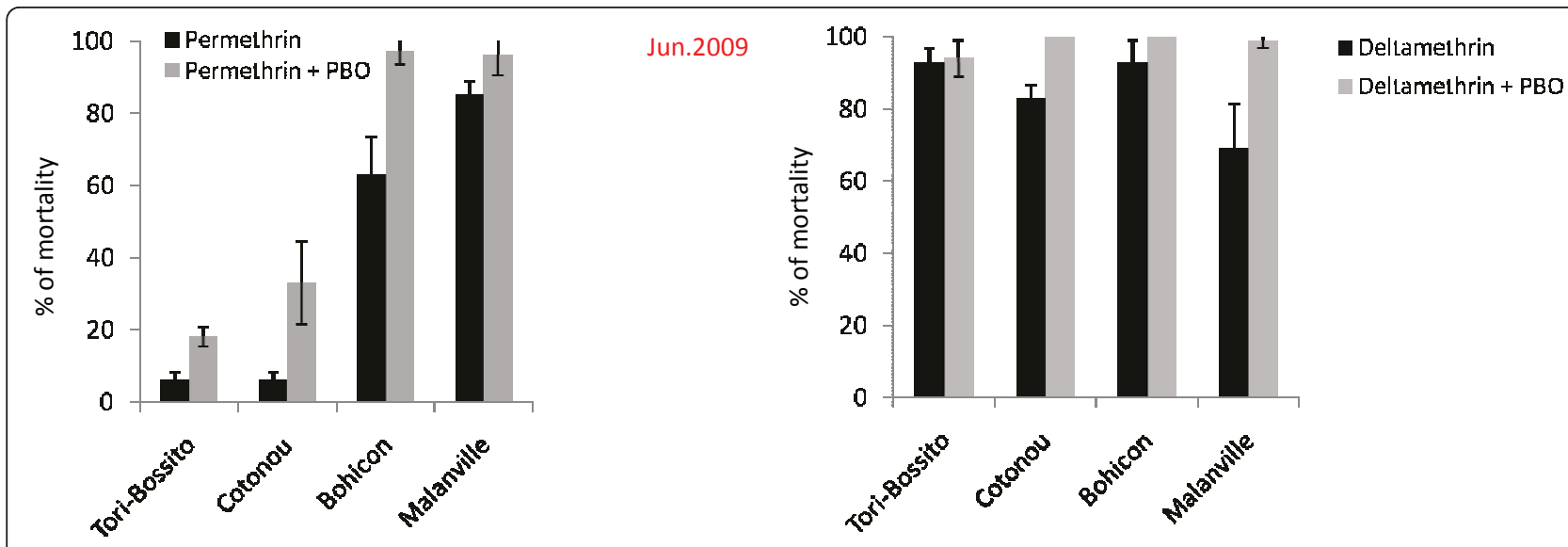

Jun.2010
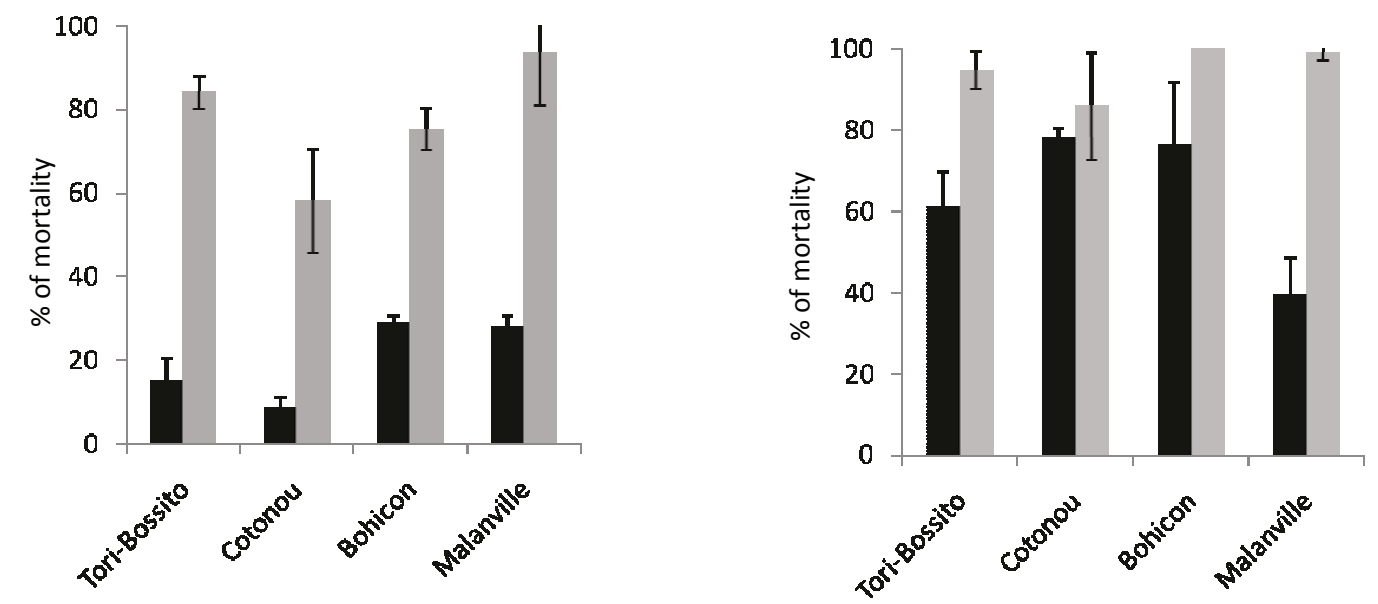

Figure 3 WHO cylinder tests showing the efficacy of pyrethroids in two collection rounds in the four sentinel sites with and without pre-exposure to the synergist PBO (Error bars are standard deviations).

substrates) was observed in Bohicon samples in both years compared to Kisumu and other field populations $(\mathrm{P}<0.0001)$ (Figure 4).

\section{Species and molecular forms of Anopheles gambiae}

Mosquitoes from bioassay (i.e. control batches) were analysed by PCR for identification of sibling species among An. gambiae s.l. complex and molecular $\mathrm{M}$ and $\mathrm{S}$ forms of An. gambiae s.s. In all sites, An. gambiae s.s was predominant over An. arabiensis (Figure 5). Only An. gambiae s.s. was found in Cotonou and Tori-Bossito while some An. arabiensis were caught in Bohicon (18\% in October 2008 versus 3\% in June 2009) and Malanville (8\% in October 2008 versus $11 \%$ in June 2009). The molecular $\mathrm{M}$ form of An. gambiae was predominant in Cotonou (urban costal area) and Malanville (rice field) whereas both $\mathrm{M}$ and $\mathrm{S}$ forms were found in sympatry in Tori-Bossito and Bohicon. A switch from $\mathrm{M}$ to $\mathrm{S}$ form occurred at the end of the rainy season (October) especially in Tori-
Bossito, hence suggesting important difference in the preference of ecological niches between the two species.

\section{Detection of resistance genes}

The L1014F kdr mutation was found in An. gambiae s.s (both $\mathrm{M}$ and $\mathrm{S}$ ) and $A n$. arabiensis but at various allelic frequencies (see Table 1). The $1014 \mathrm{~F}$ allelic frequency was high and almost fixed in the $\mathrm{M}$ form in Cotonou. In Bohicon and Malanville, the $1014 \mathrm{~F}$ allelic frequency increased significantly in $\mathrm{M}$ form from October 2008 to June 2010 ( $\mathrm{p}<0.0001)$. This increase of $k d r$ allelic frequency was positively correlated with bioassays data. The same was true at Tori-Bossito where the 1014F $k d r$ allele increased from October 2008 to October 2010 (p < 0.0001 ). Because of low number of An. arabiensis collected, the $1014 \mathrm{~F}$ allelic frequencies were not compared between the sites and round collections.

The $1014 S k d r$ allele was detected for the first time in Benin (Malanville and Bohicon in June 2010). The 


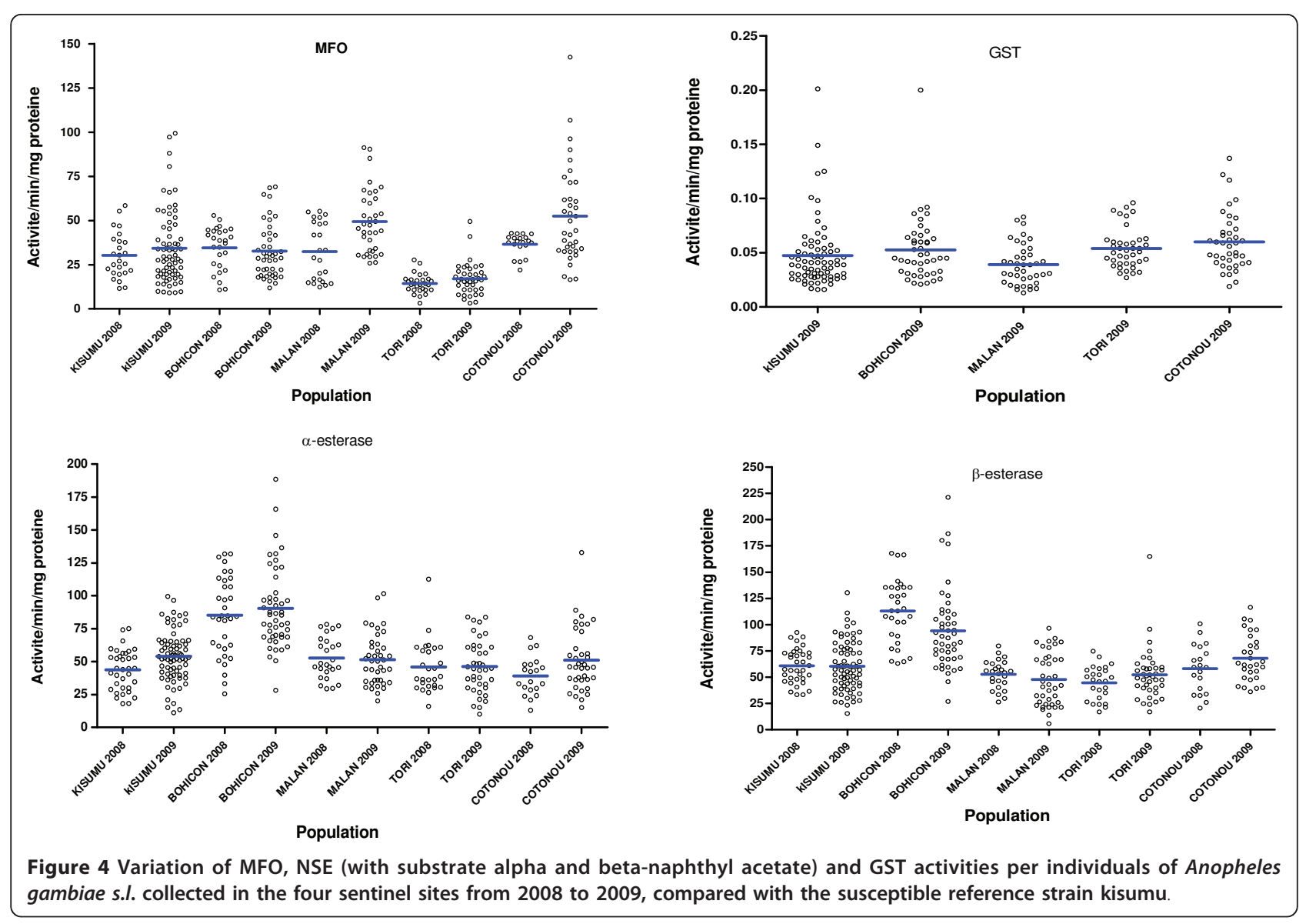

$1014 S \mathrm{kdr}$ allele was identified in five Anopheles gambiae s.l mosquitoes. Among them, three mosquitoes were identified as $A n$. arabiensis including two heterozygote from Malanville and one homozygote from Bohicon. The two other $1014 \mathrm{~S}$ positive specimens could not be clearly identified for species. The Ace. $1^{R}$ allele was only found in the heterozygote state in one specimen of An. gambiae $\mathrm{M}$ form in Bohicon.

\section{Discussion}

Information on the resistance status of the main malaria vectors is essential to guide the choice of insecticides to use by National Malaria Control Programmes. In this context, a WHO/TDR programme has been launched in five countries (Chad, Angola, Sudan, Burkina Faso and Benin) to assess the spatio-temporal variation of insecticide resistance in the main malaria vectors [6]. One of the major objectives of this network was to monitor insecticide resistance in malaria vectors in prioritized areas where largescale insecticide based control programmes are being implemented or planned by national authorities.

Regarding the distribution of malaria vector species, An. gambiae s.s was predominant in all sites, followed by $A n$. arabiensis. This is consistent with a previous studies carried out in 30 localities in Benin [50]. Consistent temporal variation in sibling species of $A n$. gambiae was observed in 2 of the 4 sentinel sites. The $M$ form was predominant in Cotonou and Malanville whereas both molecular $\mathrm{M}$ and $\mathrm{S}$ forms were found in sympatry in Bohicon and Tori-Bossito with important seasonal variation in their relative abundance. Interestingly, the $M$ form was entirely replaced by the $\mathrm{S}$ form at Tori-Bossito, at the end of the rainy season. This may be explained by the fact that the relative dominance of one molecular form over the other is strongly associated with a specific and characteristic breeding site [51]. Indeed, the $\mathrm{M}$ form in Tori-Bossito is mainly associated with domestic permanent breeding sites (i.e. water storage containers such as water tank, jars and barrels) whereas the $\mathrm{S}$ form is associated with rain-dependent temporary sites [52,53]. However, it seems that the replacement of the $M$ form by the S didn't impact on the level of DDT and pyrethroid resistance as well as on the prevalence of the $k d r$ allele i.e. the $k d r$ mutation was comparable between the two molecular forms ( $\mathrm{P}>0.05)$.

In Benin, the level of cross resistance between permethrin and DDT in An. gambiae s.l. was strong and correlated with the presence of $k d r$ mutations and enhanced 


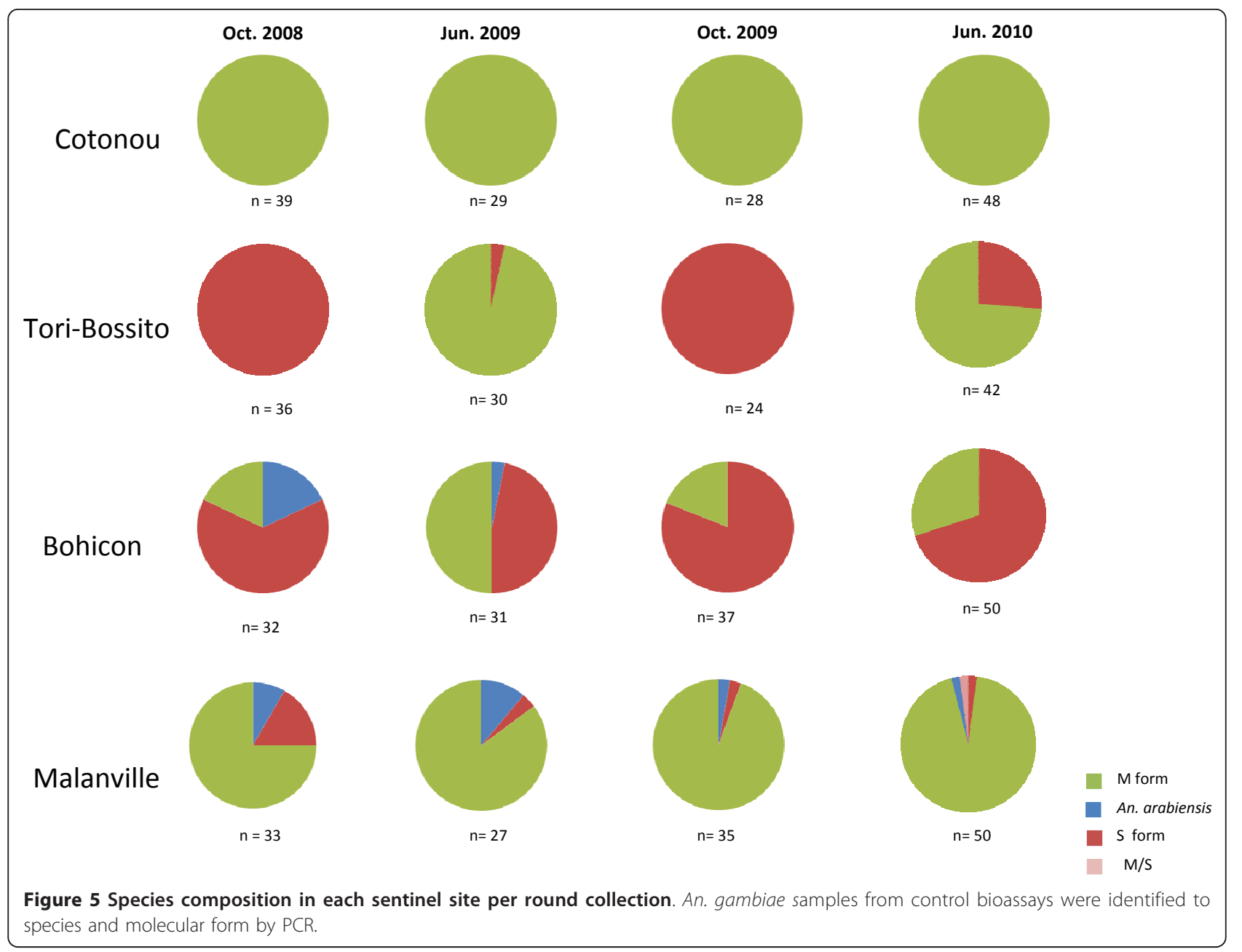

metabolic detoxification as shown by the synergist studies. Significant change in insecticide resistance and prevalence of the $k d r$ alleles were observed throughout the study. Throughout the 2 years surveys, the level of DDT and pyrethroid resistance (permethrin and deltamethrin) strongly increased in field populations, hence confirming the global augmentation of pyrethroid resistance in African malaria vectors [54]. However, important differences were noted according to the ecological setting and round collection. In Cotonou, where large amount of insecticides are applied in urban vegetable farming [31], the $k d r$ frequency was high and almost fixed whatever the round collection. Enhanced detoxification process due to higher oxidase activity was detected and seemed to play important role in resistance to DDT, permethrin and to a lesser extend deltamethrin [26]. In Bohicon, a cotton growing area where various insecticidal products (organophosphates, pyrethroids, etc.) are used to control agricultural pests, prevalence of the $k d r$ mutation increased between 2008 and 2010 precisely in the M form. Higher activity of non-specific esterase was also detected but their role in insecticide detoxification need to be clarified. This result may reflect an increase selection pressure on malaria vectors due to agricultural practices $[55,56]$. Based on strong supporting results, several authors [56-59] hypothesized that past and current agricultural use of pyrethroids, DDT and organophosphates for crop protection led to the selection of resistant individuals by challenging larval stages with residual insecticide products accumulating in water bodies around cultivated areas. Indeed, Akogbéto et al [36] demonstrated in Benin that pyrethroid resistant $A n$. gambiae larvae reared in water and soil samples taken from vegetable gardens or cotton area were able to survive and proliferate in contrast to the susceptible phenotype. In Tori-Bossito, the level of DDT and permethrin resistance as well as the prevalence of the $k d r$ frequency was initially high. However, intense malaria vector control programmes were implemented since 2007 (i.e. increased coverage of LLIN at community level), and the $k d r$ frequency increased from 0.34 in 2007 [28] to more than 0.77 in 2010 among both $\mathrm{M}$ and $\mathrm{S}$ molecular forms. Knowing the different larval habitats preferences between the $M$ and $S$ form in this locality [60], it's likely 
Table $1 \mathrm{Kdr} 1014 \mathrm{~F}$ and $1014 \mathrm{~S}$ frequencies in An.gambiae s.I per round collection and locality

\begin{tabular}{|c|c|c|c|c|c|c|c|c|c|c|}
\hline Anopheles gambiae s.I & Sites & Periods & $\mathrm{N}$ & Leu-Leu & Leu-Phe & Leu-Ser & Phe-Phe & Ser-Ser & $F(1014 F)$ & $F(1014 S)$ \\
\hline \multirow[t]{16}{*}{ M Form } & Cotonou & October 2008 & 39 & 3 & 5 & - & 31 & - & $0.85^{a}$ & - \\
\hline & & June 2009 & 29 & - & 5 & - & 24 & - & $0.91^{\mathrm{a}}$ & - \\
\hline & & October 2009 & 28 & - & 1 & - & 27 & - & $0.98^{\mathrm{b}}$ & - \\
\hline & & June 2010 & 46 & - & 9 & - & 37 & - & $0.90^{\mathrm{a}}$ & - \\
\hline & Tori-Bossito & October 2008 & - & - & - & - & - & - & - & - \\
\hline & & June 2009 & 30 & - & 5 & - & 25 & - & $0.91^{c}$ & - \\
\hline & & October 2009 & - & - & - & - & - & - & - & - \\
\hline & & June 2010 & 31 & - & 14 & - & 16 & - & $0.77^{d}$ & - \\
\hline & Bohicon & October 2008 & 7 & 5 & 1 & - & 1 & - & $0.21^{\mathrm{e}}$ & - \\
\hline & & June 2009 & 16 & - & 7 & - & 9 & - & $0.78^{f}$ & - \\
\hline & & October 2009 & 7 & - & 1 & - & 6 & - & $0.92 f^{g}$ & - \\
\hline & & June 2010 & 15 & - & 1 & - & 11 & - & $0.76^{f}$ & - \\
\hline & Malanville & October 2008 & 27 & 20 & 5 & - & 2 & - & $0.16^{\mathrm{h}}$ & - \\
\hline & & June 2009 & 26 & 18 & 7 & - & 1 & - & $0.17^{h}$ & - \\
\hline & & October 2009 & 34 & 20 & 8 & - & 6 & - & $0.29^{i}$ & - \\
\hline & & June 2010 & 44 & 12 & 20 & - & 12 & - & $0.50^{\mathrm{j}}$ & - \\
\hline \multirow[t]{12}{*}{ S Form } & Tori-Bossito & October 2008 & 36 & 8 & 12 & - & 16 & - & $0.61^{k}$ & - \\
\hline & & June 2009 & 1 & - & 1 & - & - & - & $0.50^{k}$ & - \\
\hline & & October 2009 & 24 & - & 4 & - & 20 & - & $0.91^{\prime}$ & - \\
\hline & & June 2010 & 11 & 1 & 5 & - & 5 & - & $0.68^{k}$ & - \\
\hline & Bohicon & October 2008 & 25 & 3 & 6 & - & 16 & - & $0.76^{\mathrm{m}}$ & - \\
\hline & & June 2009 & 15 & - & 1 & - & 14 & - & $0.96^{n}$ & - \\
\hline & & October 2009 & 30 & - & 3 & - & 27 & - & $0.95^{n}$ & - \\
\hline & & June 2010 & 33 & - & 7 & - & 26 & - & $0.89^{m n}$ & - \\
\hline & Malanville & October 2008 & 7 & 5 & 1 & - & 1 & - & 0.21 & - \\
\hline & & June 2009 & 1 & 1 & - & - & - & - & - & - \\
\hline & & October 2009 & 1 & 1 & - & - & - & - & - & - \\
\hline & & June 2010 & 1 & - & - & - & 1 & - & 1.00 & - \\
\hline \multirow[t]{8}{*}{ An. arabiensis } & Bohicon & October 2008 & 7 & 1 & 4 & - & 2 & - & 0.57 & - \\
\hline & & June 2009 & 1 & - & - & - & 1 & - & 1.0 & - \\
\hline & & October 2009 & 0 & - & - & - & - & - & - & - \\
\hline & & June 2010 & 2 & 1 & - & - & - & 1 & 0.5 & 0.50 \\
\hline & Malanville & October 2008 & 3 & 3 & - & - & - & - & - & - \\
\hline & & June 2009 & 3 & 3 & - & - & - & - & - & - \\
\hline & & October 2009 & 1 & 1 & - & - & - & - & - & - \\
\hline & & June 2010 & 3 & - & 1 & 2 & - & - & 0.16 & 0.33 \\
\hline
\end{tabular}

' - ' indicates no samples available for this round collection; Leu = Leucine, Phe = Phenylalanine, Ser = Serine. Nota: A further two individuals with the 1014S allele including one homozygote and one heterozygote were respectively detected in Bohicon and Malanville but their species could not be confirmed. The numbers carrying the same letter are not significantly different

that vector control intervention based on LLIN distribution has led to increase the level of pyrethroid resistance and select for $k d r$ alleles in malaria vectors. This is consistent with previous observations reporting an increase of the $k d r$ $1014 F$ frequency in An. gambiae following a nationwide distribution of long-lasting insecticide-treated nets in Niger and Kenya [41,61]. In the rice field area of Malanville, the increase in resistance to DDT and pyrethroids can reasonably be attributed to the augmentation of the $1014 \mathrm{~F} k d r$ prevalence and to higher levels of oxidase activity. Corbel et al [27] previously reported a very low frequency of the $k d r 1014 F$ frequency (0.06 in 2007) whereas in 2010, this frequency has reached $50 \%$ in the $M$ form. The sudden increase in $k d r$ frequency and pyrethroid resistance is worrying considering the relatively low amount of insecticide use in this area. It is possible that An. gambiae populations carrying the $k d r$ mutation might have migrated, through active or/and passive ways, from bordering countries (e.g. Niger, Nigeria) due to intense traffic and exchanges in this locality. Experimental huts belonging to the ABC (Anopheles, Biology and Control) network were initially built in Malanville to assist WHOPES (WHO Pesticide Evaluation Scheme) in testing and evaluation of insecticide products against susceptible malaria vectors. The increasing 
resistance pattern in Malanville highlights the difficulty in finding areas where the vector population remain pyrethroid-susceptible to conduct such trials. It is obvious that WHOPES will have to consider this trend in the development of future guidelines for testing insecticide products for IRS and LLIN.

An important result of the present study is the first report of the L1014S kdr mutation in wild An. gambiae s.l populations from Benin. The resistant allele was found in An. arabiensis. This allele has been reported in An arabiensis in Uganda [19] and Ethiopia [8]. The 1014S allele is also found in An gambiae s.s. of the M and $\mathrm{S}$ forms in Central Africa (Equatorial Guinea [62] and Cameroon [63]) but its presence in this species was not confirmed in the current study. Among the five specimens of mosquitoes sharing the $1014 \mathrm{~S}$ allele, three were found at the homozygote state and two at the heterozygote. These findings provide additional evidence of the rapid spread of $k d r$ mutations in An. gambiae s.l throughout Africa and will serve as baseline data for careful monitoring this allele in West African countries. Further studies are need to determine the geographical distribution of $1014 \mathrm{~S} \mathrm{kdr}$ allele in West Africa, its role in pyrethroid phenotypic resistance and its impact on the efficacy of pyrethroid treated materials.

Encouragingly, this study demonstrated the full susceptibility of malaria vectors to fenitrothion and bendiocarb, hence confirming the work of Djogbenou et al [13] in Benin. This susceptibility was associated with the virtual absence of the Ace. $1^{R}$ allele in the four sentinel sites. This may be explained by low selection pressure on this resistant allele in Benin and/or strong genetic cost associate with altered acetylcholinesterase [64]. This result is important for vector control since carbamates and organophosphates are regarded as potential alternatives to pyrethroids for IRS as part of an insecticide resistance management strategy $[65,66]$. Indeed, these insecticides could be used alone or in rotation with others new insecticides, such as chlorfenapyr, to counteract the development of pyrethroid resistance [67].

\section{Conclusion}

These results showed a seasonal and spatial evolution of multiple insecticide resistance in malaria vectors in Benin that may seriously compromise malaria vector control efforts implemented in the country since 2007. This study showed first evidence for the presence of the $1014 \mathrm{~S}$ $k d r$ allele in wild $A n$. arabiensis populations from Benin and West Africa and highlights the urgent need to continue monitoring of insecticide resistance in African malaria vector. The development of new tools and strategies for pyrethroid-resistance management are urgently needed.

\section{Acknowledgements}

This study received financial support from the UNICEF/UNDP/World Bank/ WHO Special Programme for Research and Training in Tropical Diseases (WHO/TDR) (Grant AY0588). Innocent Djègbè was funded by the Institut de Recherche pour le Développement (bourse IRD/DSF). We would like to acknowledge the technical support of Joseph Chabi, Armel Djènontin, Nicolas Moiroux and Sébastien Koudénoukpo.

\section{Author details}

${ }^{1}$ Centre de Recherche Entomologique de Cotonou (CREC), 06 BP 2604, Cotonou, Bénin. ${ }^{2}$ Institut de recherche pour le développement (IRD), Maladies Infectieuses et Vecteurs, Ecologie, Génétique, Evolution et Contrôle (MIVEGEC), UM1-CNRS 5290-IRD 224, 01 BP 4414 RP Cotonou, Bénin. ${ }^{3}$ Centre de Coopération Internationale en Recherche Agronomique pour le Développement (CIRAD), UR-Hortsys, 34980 Montpellier, France. ${ }^{4}$ Vector Group, Liverpool School of Tropical Medicine, Liverpool, L3 5QA, UK. ${ }^{5}$ IRD, MIVEGEC, UM1-CNRS 5290-IRD 224, Laboratoire de lutte contre les Insectes Nuisibles (LIN), Montpellier France.

\section{Authors' contributions}

ID carried out the larval collection, bioassay. ID and AS carried out the biochemical and molecular analysis. ID and VC drafted the manuscript. VC, TM, FC, HR and MA participated to the design of the study. ID and OB participated to the data analysis. All authors read and approved the final manuscript.

\section{Competing interests}

The authors declare that they have no competing interests.

Received: 21 February 2011 Accepted: 12 September 2011 Published: 12 September 2011

\section{References}

1. WHO: World Malaria Report 2010 World Health Organization, Geneva.

2. Chandre F, Darrier F, Manga L, Akogbeto M, Faye O, Mouchet J, Guillet P: Status of pyrethroid resistance in Anopheles gambiae sensu lato. Bull World Health Organ 1999, 77:230-234.

3. Djogbenou L, Dabire R, Diabate A, Kengne P, Akogbeto M, Hougard JM, Chandre F: Identification and geographic distribution of the ACE-1R mutation in the malaria vector Anopheles gambiae in south-western Burkina Faso, West Africa. Am J Trop Med Hyg 2008, 78:298-302.

4. Diabate A, Brengues C, Baldet T, Dabire KR, Hougard JM, Akogbeto M, Kengne P, Simard F, Guillet P, Hemingway J, Chandre F: The spread of the Leu-Phe kdr mutation through Anopheles gambiae complex in Burkina Faso: genetic introgression and de novo phenomena. Trop Med Int Health 2004, 9:1267-1273.

5. Zaim M, Aitio A, Nakashima N: Safety of pyrethroid-treated mosquito nets. Med Vet Entomol 2000, 14:1-5.

6. Ranson H, Abdallah H, Badolo A, Guelbeogo WM, Kerah-Hinzoumbe C, Yangalbe-Kalnone E, Sagnon N, Simard F, Coetzee M: Insecticide resistance in Anopheles gambiae: data from the first year of a multi-country study highlight the extent of the problem. Malar J 2009, 8:299.

7. Santolamazza F, Calzetta M, Etang J, Barrese E, Dia I, Caccone A, Donnelly MJ, Petrarca V, Simard F, Pinto J, della Torre A: Distribution of knock-down resistance mutations in Anopheles gambiae molecular forms in west and west-central Africa. Malar J 2008, 7:74.

8. Yewhalaw D, Bortel WV, Denis L, Coosemans M, Duchateau L, Speybroeck N: First evidence of high knockdown resistance frequency in Anopheles arabiensis (Diptera: Culicidae) from Ethiopia. Am J Trop Med Hyg 2010, 83:122-125.

9. Casimiro S, Coleman M, Hemingway J, Sharp B: Insecticide resistance in Anopheles arabiensis and Anopheles gambiae from Mozambique. J Med Entomol 2006, 43:276-282.

10. Vulule JM, Beach RF, Atieli FK, MCAllister JC, Brogdon WG, Roberts JM, Mwangi RW, Hawley WA: Elevated oxidase and esterase levels associated with permethrin tolerance in Anopheles gambiae from Kenyan villages using permethrin-impregnated nets. Med Vet Entomol 1999, 13:239-244.

11. Etang J, Manga L, Chandre F, Guillet P, Fondjo E, Mimpfoundi R, Toto JC, Fontenille D: Insecticide susceptibility status of Anopheles gambiae s.l. 
(Diptera: Culicidae) in the Republic of Cameroon. J Med Entomol 2003, 40:491-497.

12. Hemingway J, Hawkes NJ, McCarroll L, Ranson H: The molecular basis of insecticide resistance in mosquitoes. Insect Biochem Mol Biol 2004, 34:653-665.

13. Djogbenou L, Pasteur N, Akogbeto M, Weill M, Chandre F: Insecticide resistance in the Anopheles gambiae complex in Benin: a nationwide survey. Med Vet Entomol 2009, 69:160-164.

14. Ranson $H$, Jensen B, Vulule JM, Wang $X$, Hemingway J, Collins FH: Identification of a point mutation in the voltage-gated sodium channel gene of Kenyan Anopheles gambiae associated with resistance to DDT and pyrethroids. Insect Molecular Biology 2000, 9:491-497.

15. Nwane P, Etang J, Chouaibou M, Toto JC, Kerah-Hinzoumbe C, Mimpfoundi R, Awono-Ambene HP, Simard F: Trends in DDT and pyrethroid resistance in Anopheles gambiae s.s. populations from urban and agro-industrial settings in southern Cameroon. BMC Infect Dis 2009, 9:163.

16. Ndjemai HN, Patchoke S, Atangana J, Etang J, Simard F, Bilong CF, Reimer L, Cornel A, Lanzaro GC, Fondjo E: The distribution of insecticide resistance in Anopheles gambiae s.l. populations from Cameroon: an update. Trans R Soc Trop Med Hyg 2009, 10:1016.

17. Janeira F, Vicente $J L$, Kanganje $Y$, Moreno M, do R, rio VE, Cravo P, Pinto J: A Primer-introduced restriction analysis-polymerase chain reaction method to detect knockdown resistance mutations in Anopheles gambiae. J Med Entomol 2008, 45:237-241.

18. Pinto J, Lynd A, Elissa N, Donnelly MJ, Costa C, Gentile G, Caccone A, do Rosario VE: Co-occurrence of East and West African kdr mutations suggests high levels of resistance to pyrethroid insecticides in Anopheles gambiae from Libreville, Gabon. Med Vet Entomol 2006, 20:27-32.

19. Verhaeghen K, Van Bortel W, Roelants P, Backeljau T, Coosemans M: Detection of the East and West African kdr mutation in Anopheles gambiae and Anopheles arabiensis from Uganda using a new assay based on FRET/Melt Curve analysis. Malar J 2006, 5:16.

20. Henry MC, Assi SB, Rogier C, Dossou-Yovo J, Chandre F, Guillet P, Carnevale P: Protective efficacy of lambda-cyhalothrin treated nets in Anopheles gambiae pyrethroid resistance areas of Côte d'Ivoire. Am J Trop Med Hyg 2005, 73:859-864

21. Darriet F, N' guessan R, Koffi AA, Konan L, Doannio JMC, Chandre F, Carnevale P: Impact of the resistance to pyrethroids on the efficacy of impregnated bednets used as a means of prevention against malaria: results of the evaluation carried out with deltamethrin SC in experimental huts] (Impact de la résistance aux pyréthrinoïdes sur l'efficacité des moustiquaires imprégnées dans la prévention du padulisme: résultats des essais en cases expérimentales avec la deltaméthrine SC). Bull Soc Path Exot 2000, 93:131-134.

22. Vulule JM, Beach RF, Atieli FK, MCAllister JC, Brogdon WG, Roberts JM, Mwangi RW, Hawley WA: Elevated oxidase and esterase levels associated with permethrin tolerance in Anopheles gambiae from Kenyan villages using permethrin-impregnated nets. Med Vet Entomol 1999, 13:239-244.

23. Ranson H, Jensen B, Wang X, Prapanthadara L, Hemingway J, Collins FH: Genetic mapping of two loci affecting DDT resistance in the malaria vector Anopheles gambiae. Insect Mol Biol 2000, 9:499-507.

24. Damien GB, Djènontin A, Rogier $C$, Corbel V, Bangana SB, Chandre F, Akogbeto M, Kinde-Gazard D, Massougbodji A, Henry MC: Malaria infection and disease in an area with pyrethroid-resistant vectors in southern Benin. Malar J 2010, 9:380.

25. Yadouleton AW, Padonou G, Asidi A, Moiroux N, Bio-Banganna S, Corbel V, N'Guessan R, Gbenou D, Yacoubou I, Gazard K, Massougbodji A, Akogbéto M: Insecticide resistance status in Anopheles gambiae in southern Benin. Malar J 2010, 9:83.

26. Djouaka RF, Bakare AA, Coulibaly ON, Akogbeto MC, Ranson $H$, Hemingway J, Strode C: Expression of the cytochrome P450s, CYP6P3 and CYP6M2 are significantly elevated in multiple pyrethroid resistant populations of Anopheles gambiae s.s. from Southern Benin and Nigeria. BMC Genomics 2008, 9:538.

27. Corbel V, N'Guessan R, Brengues C, Chandre F, Djogbenou L, Martin T, Akogbeto M, Hougard JM, Rowland M: Multiple insecticide resistance mechanisms in Anopheles gambiae and Culex quinquefasciatus from Benin, West Africa. Acta Trop 2007, 101:207-216.

28. Djènontin A, Bio-Bangana $S$, Moiroux N, Henry MC, Bousari O, Chabi J, Ossè R, Koudénoukpo $S$, Corbel V, Akogbéto $M$, Chandre F: Culicidae diversity, malaria transmission and insecticide resistance alleles in malaria vectors in Ouidah-Kpomasse-Tori district from Benin (West Africa): A pre-intervention study. Parasit Vectors 2010, 3:83.

29. Dabire KR, Diabate A, Namontougou M, Djogbenou L, Kengne P, Simard F, Bass C, Baldet T: Distribution of insensitive acetylcholinesterase (ace-1R) in Anopheles gambiae s.l. populations from Burkina Faso (West Africa). Trop Med Int Health 2009, 14:396-403.

30. Ahoua Alou LP, Koffi AA, Adja MA, Tia E, Kouassi PK, Kone M, Chandre F: Distribution of ace- $1 \mathrm{R}$ and resistance to carbamates and organophosphates in Anopheles gambiae s.s. populations from Côte d'Ivoire. Malar 」 9:167.

31. Akogbeto MC, Djouaka R, Noukpo H: [Use of agricultural insecticides in Benin] (L'utilisation des insecticides en agriculture au Bénin). Bull Soc Pathol Exot 2005, 98:400-405.

32. Anon: Le Coton au Bénin: rapport de consultation sur le coton conventionnel et le coton biologique au Bénin A report for PAN UK's Pesticides Poverty and Livelihoods project Organisation Béninoise pour la Promotion de l'Agriculture Biologique; 2002, 36.

33. IFDC: L'état du marché des intrants agricoles au Bénin. Technical Bulletin 2005, , IFDC-T70 May: 83

34. Tiamiyou I: Mission de consultation en phytotechnie maraîchère du 30 juillet au 12 août 1995 1995, 30, Rapport phase 1, Situation actuelle FAO.

35. PADAP: Rapport de l'étude diagnostic: demande, offre et marchés et système de production Tome 2 Agrisud International; 2003, 148.

36. Akogbeto MC, Djouaka RF, Kinde-Gazard DA: Screening of pesticide residues in soil and water samples from agricultural settings. Malar J 2006, 5:22.

37. PNLP: Evaluation (par la méthode LQAS) de la campagne intégrée d'octobre 2007 de distribution des MIILD, de l'Albendazole et de la vitamine A aux enfants de moins de cina ans et du niveau de quelques indicateurs de suivi de la lutte contre le paludisme 2009, Rapport.

38. Corbel V, Chandre F, Brengues C, Akogbeto M, Lardeux F, Hougard JM, Guillet P: Dosage-dependent effects of permethrin-treated nets on the behaviour of Anopheles gambiae and the selection of pyrethroid resistance. Malar J 2004, 3:22.

39. Asidi AN, N'Guessan R, Koffi AA, Curtis CF, Hougard JM, Chandre F, Corbel V, Darriet F, Zaim M, Rowland MW: Experimental hut evaluation of bednets treated with an organophosphate (chlorpyrifos-methyl) or a pyrethroid (lambdacyhalothrin) alone and in combination against insecticide-resistant Anopheles gambiae and Culex quinquefasciatus mosquitoes. Malar J 2005, 4:25.

40. Sharp BL, Ridl FC, Govender D, Kuklinski J, Kleinschmidt I: Malaria vector control by indoor residual insecticide spraying on the tropical island of Bioko, Equatorial Guinea. Malar J 2007, 6:52.

41. Czeher C, Labbo R, Arzika I, Duchemin JB: Evidence of increasing Leu-Phe knockdown resistance mutation in Anopheles gambiae from Niger following a nationwide long-lasting insecticide-treated nets implementation. Malar J 2008, 7:189.

42. WHO: Tests procedures for insecticide resistance monitoring in malaria vector, bio-efficacy and persistence of insecticides on treated surfaces 1998, 12:43, WHO/CDS/CPC/MAL/98.

43. WHO: Supplies for monitoring insecticide resistance in disease vectors Springer Eds; 2001, WHO/CDS/CPE/PVC/20012 2001

44. Hemingway J, Hawkes N, Prapanthadara L, Jayawardenal KG, Ranson H: The role of gene splicing, gene amplification and regulation in mosquito insecticide resistance. Philos Trans R Soc Lond B Biol Sci 1998, 353:1695-1699.

45. Scott JA, Brogdon WG, Collins FH: Identification of single specimens of the Anopheles gambiae complex by the polymerase chain reaction. Am $J$ Trop Med Hyg 1993, 49:520-529.

46. Favia G, Della Torre A, Bagayoko M, Lanfrancotti A, Sagnon NF, Toure Y, Coluzzi M: Molecular identification of sympatric chromosomal forms of Anopheles gambiae and futher evidence of their reproductive isolation. Insect Mol Biol 1997, 6:377-383.

47. Lynd A, Ranson H, McCall PJ, Randle NP, Black WCt, Walker ED, Donnelly MJ: A simplified high-throughput method for pyrethroid knockdown resistance (kdr) detection in Anopheles gambiae. Malar J 2005, 4:16.

48. Weill M, Malcolm C, Chandre F, Mogensen K, Berthomieu A, Marquine M, Raymond $\mathrm{M}$ : The unique mutation in ace-1 giving high insecticide resistance is easily detectable in mosquito vectors. Insect Mol Biol 2004, 13:1-7. 
49. Raymond M, Rousset F: GENEPOP Version 1.2 A population genetics software for exact tests and ecumenicism. J Heredity 1995, 26:248-249.

50. Djogbenou L, Pasteur N, Bio-Bangana S, Baldet T, Irish SR, Akogbeto M, Weill $M$, Chandre F: Malaria vectors in the Republic of Benin: Distribution of species and molecular froms of the Anopheles gambiae complex. Acta Trop 2010, 114:, 116-122.

51. Costantini C, Ayala D, Guelbeogo WM, Pombi M, Some CY, Bassole $\mathbb{H}$ Ose K, Fotsing JM, Sagnon N, Fontenille D, Besansky NJ, Simard F: Living at the edge: biogeographic patterns of habitat segregation conform to speciation by niche expansion in Anopheles gambiae. BMC ECOl 2009, 9:16.

52. Dabire KR, Diabate A, Agostinho F, Alves F, Manga L, Faye O, Baldet T: Distribution of the members of Anopheles gambiae and pyrethroid knock-down resistance gene (kdr) in Guinea-Bissau, West Africa. (Distribution des espèces du complexe Anopheles gambiae et du gène de résistance aux pyréthrinoïdes, kdr en Guinée-Bissau, Afrique de I'Ouest.). Bull Soc Pathol Exot 2008, 101:119-123.

53. Diabate A, Baldet T, Chandre F, Dabire KR, Kengne P, Guiguemde TR, Simard F, Guillet P, Hemingway J, Hougard JM: KDR mutation, a genetic marker to assess events of introgression between the molecular $\mathrm{M}$ and $\mathrm{S}$ forms of Anopheles gambiae (Diptera: Culicidae) in the tropical savannah area of West Africa. J Med Entomol 2003, 40:195-198.

54. Ranson H, N'Guessan R, Lines J, Moiroux N, Nkuni Z, Corbel V: Pyrethroid resistance in African anopheline mosquitoes: what are the implications for malaria control. Trends Parasitol 2011, 27:91-98.

55. Baber I, Keita M, Sogoba N, Konate M, Diallo M, Doumbia S, Traore SF, Ribeiro JM, Manoukis NC: Population size and migration of Anopheles gambiae in the Bancoumana Region of Mali and their significance for efficient vector control. PLoS One 2010, 5:e10270.

56. Diabate A: The role of agricultural uses of insecticides in resistance to prethroids in Anopheles gambiae S.L. in Burkina Faso. Am J Trop Med Hyg 2002, 67:617-622.

57. Chouaibou M, Etang J, Brevault T, Nwane P, Hinzoumbe CK, Mimpfoundi R, Simard F: Dynamics of insecticide resistance in the malaria vector Anopheles gambiae s.l. from an area of extensive cotton cultivation in Northern Cameroon. Trop Med Int Health 2008, 13:476-486.

58. Tia E, Akogbeto M, Koffi A, Toure M, Adja AM, Moussa K, Yao T, Carnevale P, Chandre E: [Pyrethroid and DDT resistance of Anopheles gambiae s.s. (Diptera: Culicidae) in five agricultural ecosystems from Côte-d'Ivoire] [Situation de la résistance d'Anopheles gambiae s.s (Diptera: Culicidae) aux pyréthroïdes et au DDT dans cinq écosystèmes agricoles de Côted'Ivoire]. Bull Soc Pathol Exot 2006, 99:278-282.

59. Yawson AE, McCall PJ, Wilson MD, Donnelly MJ: Species abundance and insecticide resistance of Anopheles gambiae in selected areas of Ghana and Burkina Faso. Med Vet Entomol 2004, 18:372-377.

60. Bangana ASB, Djènontin A, Moiroux N, Ossé R, Chabi J, Koudénoukpo S, Boko $\mathrm{M}$, Chandre F, Corbel V: Characterization of the mosquitoes fauna in Ouidah, Kpomassé and Tori-Bossito health district in Southern Benin. Nairobo Kenya: 5th MIM Pan-African Malaria Conference 2009.

61. Stump AD, Atieli FK, Vulule JM, Besansky NJ: Dynamics of the pyrethroid knockdown resistance allele in western Kenyan populations of Anopheles gambiae in response to insecticide-treated bed net trials. Am J Trop Med Hyg 2004, 70:591-596.

62. Ridl F, Bass C, Torrez M, Govender D, Ramdeen V, Yellot L, Edu A, Schwabe C, Mohloai P, Maharaj R, Kleinschmidt I: A pre-intervention study of malaria vector abundance in Rio Muni, Equatorial Guinea: Their role in malaria transmission and the incidence of insecticide resistance alleles. Malaria Journal 2008, 7:194.

63. Reimer L, Fondjo E, Patchoke S, Diallo B, Lee $Y$, Arash NG, Ndjemai HM, Atangana J, Traore SF, Lanzaro G, Cornel AJ: Relationship between kdr mutation and resistance to pyrethroid and DDT insecticides in natural populations of Anopheles gambiae. J Med Entomol 2008, 45:260-266.

64. Djogbenou L, Noel V, Agnew P: Costs of insensitive acetylcholinesterase insecticide resistance for the malaria vector Anopheles gambiae homozygous for the G119S mutation. Malar J 2010, 9:12.

65. Akogbéto MC, Padonou GG, Gbénou D, Irish S, Yadouleton A: Bendiocarb, a potential alternative against pyrethroid resistant Anopheles gambiae in Benin, West Africa. Malar J 2010, 9:204.

66. Djenontin A, Chabi J, Baldet T, Irish S, Pennetier C, Hougard JM, Corbel V, Akogbeto $\mathrm{M}$, Chandre F: Managing insecticide resistance in malaria vectors by combining carbamate-treated plastic wall sheeting and pyrethroid-treated bed nets. Malar J 2009, 8:233.

67. N'Guessan R, Boko P, Odjo A, Knols B, Akogbeto M, Rowland M: Control of pyrethroid-resistant Anopheles gambiae and Culex quinquefasciatus mosquitoes with chlorfenapyr in Benin. Trop Med Int Health 2009, 14:389-395.

doi:10.1186/1475-2875-10-261

Cite this article as: Djègbè et al:: Dynamics of insecticide resistance in malaria vectors in Benin: first evidence of the presence of L1014S kdr mutation in Anopheles gambiae from West Africa. Malaria Journal 2011 $10: 261$

\section{Submit your next manuscript to BioMed Central and take full advantage of:}

- Convenient online submission

- Thorough peer review

- No space constraints or color figure charges

- Immediate publication on acceptance

- Inclusion in PubMed, CAS, Scopus and Google Scholar

- Research which is freely available for redistribution 